\title{
Relationship between Adversity Quotient and English Proficiency at the English Language Teaching Department
}

\author{
Agil Abdur Rohim $^{1}$, Siusana Kweldju ${ }^{1}$ \\ ${ }^{1}$ Pendidikan Bahasa Inggris-Universitas Negeri Malang
}

\begin{tabular}{l}
\hline \hline INFO ARTIKEL \\
\hline Riwayat Artikel: \\
Diterima: 29-05-2019 \\
Disetujui: $17-09-2019$ \\
\hline
\end{tabular}

\section{Kata kunci:}

adversity quotient; english proficiency, TOEIC

\begin{abstract}
ABSTRAK
Abstract: This quantitative study examined the role of AQ on English proficiency. The four dimensions of AQ named Control (x1), Ownership (x2), Reach (x3) and Endurance $(\mathrm{x} 4)$ were independent variables while TOEIC score $(y)$ was dependent variable. The subjects were 77 students of ELT Department. The result showed that AQ had influenced $15.9 \%\left(\mathrm{R}^{2}=.159\right)$ to TOEIC score. There was significant influence of CORE to TOEIC score simultaneously $\left(\mathrm{F}>\mathrm{F}_{\text {table }}=3.44>2.33\right)$. Nevertheless, the result of partial regression analysis showed only Control $\left(\mathrm{t}>\mathrm{t}_{\text {table }}=2.89>1.66\right)$ had significantly influenced TOEIC. Thus, this research had statistically proven that AQ provided minor contribution to students' English Proficiency.
\end{abstract}

\begin{abstract}
Abstrak: Penelitian kuantitatif ini menguji pengaruh Kecerdasan Adversiti terhadap kecakapan berbahasa Inggris. Empat dimensi Kecerdasan Adversiti, yakni kontrol (x1), kepemilikan (x2), pencapaian (x3), dan ketahanan (x4) adalah variabel bebas sementara skor TOEIC adalah variabel terikat. Hasil menunjukkan bahwa Kecerdasan Adversity berpengaruh $15.9 \%\left(\mathrm{R}^{2}=.159\right)$ terhadap skor TOEIC. Terdapat pengaruh signifikan emapt dimensi Kecerdasan Adversiti terhadap skor TOEIC secara simultan $\left(\mathrm{F}>\mathrm{F}_{\text {table }}=3.44>2.33\right)$. Namun, hasil regresi parsial menunjukkan hanya kontrol $\left(\mathrm{t}>\mathrm{t}_{\text {table }}=2.89>1.66\right)$ yang memberikan pengaruh signifikan terhadap skor TOEIC. Penelitian ini telah membuktikan secara statistik bahwa Kecerdasan Adversity hanya memberikan kontribusi minor terhadap kecakapan siswa berbahasa Inggris.
\end{abstract}

\section{Alamat Korespondensi:}

Agil Abdur Rohim

Pendidikan Bahasa Inggris

Universitas Negeri Malang

Jalan Semarang 5 Malang

E-mail: agilabdurrohim@gmail.com

Stakeholders in education, including researchers have long been interested in exploring variables as potential predictors of academic achievement (Bakare, 2015). The explored variables observed by researchers have concerned much on Intellectual Quotient (IQ) and Emotional Quotient (EQ) which are believed to be the most dominant predictors (Venkatesh \& Shivaranjani, 2016). While IQ and EQ are being studied and explained on how it affects academic achievement, some researchers still investigate for other factors (Mohzan, Hassan, \& Halil, 2013). The search continues until several research findings by abundant researchers (Bakare, 2015; City, 2009; Praditsang, Hanafi, \& Walters, 2015) offer Adversity Quotient as alternative predictor of academic success, achievement, and performance. Adversity quotient was introduced in 1997 by Californian consultant named Dr. Paul Stoltz. He had conducted 20 years research and 10 years application concerned on mapping human's resilience (Stoltz, 1997). Introduced as the science of human resilience, he explained that AQ comprised of three major sciences: Cognitive Psychology, Psychoneuroimmunology, and Neurophysiology. The three major sciences serve as the foundation or building blocks of AQ are described below as cited in (Stoltz, 1997).

The first building block is cognitive psychology. It is defined as that which deals with how people perceive, learn, remember, and think about information (Stenberg \& Stenberg, 2012). This building block is comprised of the extensive and growing body of research related to the human need for control or mastery over one's life. It includes some essential concepts for understanding human motivation, effectiveness, and performance

The second building block, which is Psychoneuroimmunology. It refers to the study of the interactions among behavioral, neural, and endocrine, and immune functions (Ader, 2000). It observers direct link between one's response to adversity and his or her mental health and physical health, and that how one responds to adversity (AQ®) influences immune functions, recovery from surgery, and vulnerability to life-threatening disease.

The third building block is Neurophysiology. It is the branch of physicology dealing with the functions of the nervous system (Rogawski, 2017). The correlation of neurophysiology and adversity quotient lies that the brain ideally equipped to form habits. Those habits can be instantly interrupted and changed thus, become hardwired in the subconscious region of the brain. Subconscious habits, such as $\mathrm{AQ}{ }^{\circledR}$, can be immediately altered, readily forming new habits that are strengthened over time. 
In short, (Stoltz, 1997; Wilson, 1999) claimed that the combination of three building blocks: cognitive psychology, psychoneuroimmunology, and neurophysiology resulted a new understanding, measurement, and set of tools to enhance human effectiveness.

In correspondence with the development of the science of human resilience, (Stoltz, 1997) defined AQ in three forms. The first form was AQ as new conceptual framework for understanding all facets of adversities. It built upon a substantial base of landmark research, applied research, and combination of knowledge. The second form was AQ as measurement to map out how individual responds adversities. The last form was as scientifically-grounded practical tools for improving personal and professional effectiveness. The combination of conceptual framework, measurement, and practical tools generated a complete package for understanding and improving fundamental component of the daily and lifelong ascent.

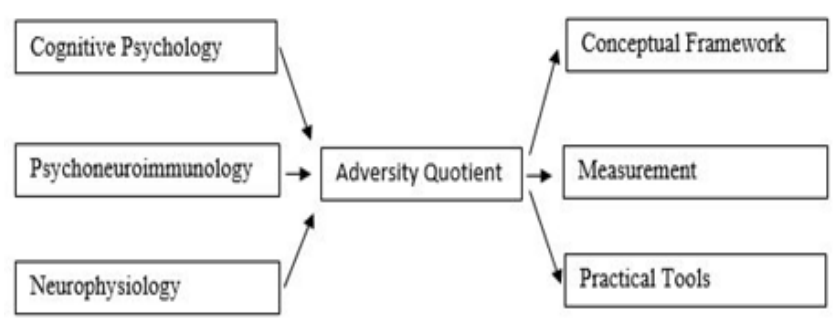

Figure 1. Unity Consilience of Adversity Quotient

The building blocks and forms of Adversity Quotient as science of human resilience resonance with Wilson's Theory of Consilience: The Unity of Knowledge (Wilson, 1999). He theorized that one discipline needed the strength of evidences and approaches from other related disciplines. This conception was named consilience, as coined by Wilson. In addition, Joseph (Carroll, 1999) also explained that consilience decreased the possibility of errors by synthesizing knowledge through similar findings from related multidisciplinary studies. He strengthened his statement by adding that the findings correspondingly acted as justification to enhance quality of the conclusion that contribute to the generated discipline.

Within the consilience of Adversity Quotient, each discipline from the building blocks contributed to specific concept that essential to the theory of AQ: cognitive psychology generated the explanation of human information processing, psychoneuroimmunology provided understanding of human's vulnerability to life-threatening phenomena, and neurophysiology mapped out human's habit construction. Therefore, based on the detailed explanation about the contribution of each discipline, the development of Adversity Quotient has been linear with Wilson's theory of consilience.

Based on the strong foundation of the building blocks, forms, and the conformity of Wilson's theory of consilience, Stoltz proposed AQ as an emerging conceptual framework for understanding and enhancing all facets of succeed (Marashi \& Fotoohi, 2017). Nonetheless, this claim needs to be cautiously examined. There have been numerous studies that propose the use of AQ. For instance, (Matore, Khairani, \& Razak, 2015) asserted that AQ can predict resilience and persistence of a person and can be used to enhance the effectiveness of teams, classes, communities, and societies. Another research (Venkatesh \& Shivaranjani, 2016) appointed the importance of AQ in the workforce, specifically to the organizational capacity.

In the academic field, Adversity Quotient plays important role as being potential predictor to individual achievement (Stoltz, 1997; Tripathi, 2011). AQ should necessarily be explored as it reveals the students' resilience and serves as a predictor besides Intellectual Quotient (IQ) and Emotional Quotient (EQ) on students' achievement (Stoltz, 1997). There are numerous evidences that support the prior statement. (Suryadi \& Santoso, 2017) have shown that Adversity Quotient does influences students' achievement in Mathematics. In Indonesia, another research has shown that Adversity Quotient improves problem solving ability (Sihaloho \& Sahyar, 2017). In addition, there was a study conducted in Malang showed that Adversity Quotient contributed to the students' achievement in secondary school (Rahmayani, 2013).

In the English Language Teaching (ELT) context, Adversity Quotient is not a renowned area of investigation. Nevertheless, there is a limited source of research finding related to this concept. Apparently, there is a huge potential for Adversity Quotient to be a predictor of achievement beside Intellectual Quotient (IQ) and Emotional Quotient (EQ) (Tripathi, 2011). In line with (Matore et al., 2015) conducted research in four different regions: Northern, Southern, Eastern, and Western of Borneo, demonstrated that Adversity Quotient played imperative role on students' academic achievement. Based on the simple regression analysis, AQ was proven to have association with students' achievement. It was also showed that Adversity Quotient was correlational with the other four intelligences: Intellectual, Emotional, Spiritual, and Physical Quotient that supported academic achievement. 
Within the context of education, AQ is interpreted as students' ability to keep on track of learning goals when facing some difficulties. Basically, AQ predicts resilience and persistence of a person. According to (Stoltz, 1997), Adversity Quotient (AQ) encapsulates four dimensions named CORE. It stands for Control, Ownership, Reach, and Endurance. Control begins with the perception that something works under certain intentional condition. Control criteria defines on how and to what extent a person faces certain phenomena. Ownership refers to how a person seeks to determine the cause and sense of belonging to an event. Reach addresses the limitation of a person and how he or she takes advantages of adverse conditions. Those four dimensions are combined to form a person's AQ. The tendency of each dimension is described in the table 1.

Table 1. Depict Interpretation of CORE Dimension (Stoltz, 1997)

\begin{tabular}{lll}
\hline Dimension & \multicolumn{1}{c}{ Definition } & \multicolumn{1}{c}{ Tendency } \\
\hline Control & $\begin{array}{l}\text { The extent to which someone perceives the can } \\
\text { influence whatever happens next }\end{array}$ & Resilience and tenacity \\
\hline Ownership & $\begin{array}{l}\text { The likelihood that someone actually do anything } \\
\text { to improve the situation regardless of their formal responbilities }\end{array}$ & $\begin{array}{l}\text { Accountability, responsibility, action, } \\
\text { and engagement }\end{array}$ \\
\hline Reach & $\begin{array}{l}\text { To extend to which someone perceives and adversity } \\
\text { reach into and affect other aspects of the situation or their life }\end{array}$ & Burden, stress, energy, and effort \\
\hline Endurance & $\begin{array}{l}\text { The length of time the individual perceives } \\
\text { the situation / adversity last or endures }\end{array}$ & $\begin{array}{l}\text { Hope, optimism, and willingness } \\
\text { to persevere }\end{array}$ \\
\hline
\end{tabular}

In order to observe students' AQ, there is an instrument used worldwide. Developed by Stoltz himself, Adversity Response Profile (ARP) is an oppositional, scale-based, questionnaire designed to gauge an individual's resilience; that is, their capacity to respond constructively to difficulties by eliciting their hardwired response pattern to a broad range of adverse events (Stoltz, 1997). The instrument has been tested across 500.000 respondents from 51 countries, and has demonstrated strong universality applicability across cultures (Venkatesh \& Shivaranjani, 2016). Related to its reliability, a study conducted by Education Testing Service (ETS) in the US addressed to CORE dimension has shown to be highly reliable. Reliability (Cronbach's Alpha) ranges from zero to one. Repeating the analysis, self-determining studies conducted by ETS (the producer of the SAT), the AQ Profile and each of its CORE dimensions have shown to be highly reliable, or consistent. The profile has an overall reliability of .91 , higher than most popularly accepted psychological instruments and achievement tests. Related to the scaling procedure, AQ scores range from 0 to 200. The score obtained by individuals reflect on what level they are in. There are Quitters for lower score, Campers for medium, and Climbers for the top.

Table 2. Depict Interpretation of AQ Levels (Stoltz, 1997)

\begin{tabular}{|c|c|c|}
\hline & AQ Score & Interpretation \\
\hline Climbers & $0-94$ & $\begin{array}{l}\text { Typically have high AQ scores and a tremendous capacity for challenge and change. } \\
\text { Climbers tent to: } \\
\text { Be resilient and tenacious } \\
\text { Focus on solutions over blame } \\
\text { Be trusting and agile }\end{array}$ \\
\hline Campers & $95-134$ & $\begin{array}{l}\text { Typically have moderate AQ score and some capacity for challenge and change. } \\
\text { Campers tend to: } \\
\text { Let adversity wear them down } \\
\text { Resort to blame when tense or tired } \\
\text { Lose hpe and faith when adversity is high }\end{array}$ \\
\hline Quitters & $135-200$ & $\begin{array}{l}\text { Typically have lower scores and a limited capacity for challenge and change. } \\
\text { Quitters tend to: } \\
\text { Blame others } \\
\text { Become overwhelmed } \\
\text { Allow adversity to endure longer than necessary. }\end{array}$ \\
\hline
\end{tabular}

Firstly, the range of 0-94 ARP score is classified as Quitters. They can be described as being lethargic, not motivated, and complacent individual. They tend to think as victims, beaten down, exhausted, and are often in poor health. Quitters have compromised lives as they live as just the way it is. As students, quitters try to avoid the learning process as much as possible. Furthermore, they incline to consider their study as a heavy burden. 
Secondly, those who get 95-134 ARP score are grouped as Campers. They are a group of people who have taken on the mountain; they grow, they strive, they improve for years or decades. Their performance is solid and getting the assignment done. However, their capacity to overcome challenge do not grow. In contrast with quitters, campers contemplate their study as a process they have to pass. They learn about the materials, do the exercises, and pass the subject with average score.

Lastly, the highest level is Climbers, addressed to those who obtain 135-200. They are dedicated to a lifelong ascent. They are described as enthusiastic, innovative, energetic, robust, passionate, and thriving on change by taking risks. They never allow any obstacle to get in the way of the ascent. Climber students consider obstacles and problems as challenges in order to make one is better than another. They fully recognize what they have to know and why. Furthermore, climbers tend to do their best in every task they are given in.

The quitters, campers, and climbers truly exist in English language classroom. Nonetheless, their existence are often considered unnoticed. This phenomenon probably occurs because the conception of Adversity Quotient is often observed in ELT studies. Nevertheless, AQ has its own role in the renowned model of classroom interaction by Dunkin and Biddle.

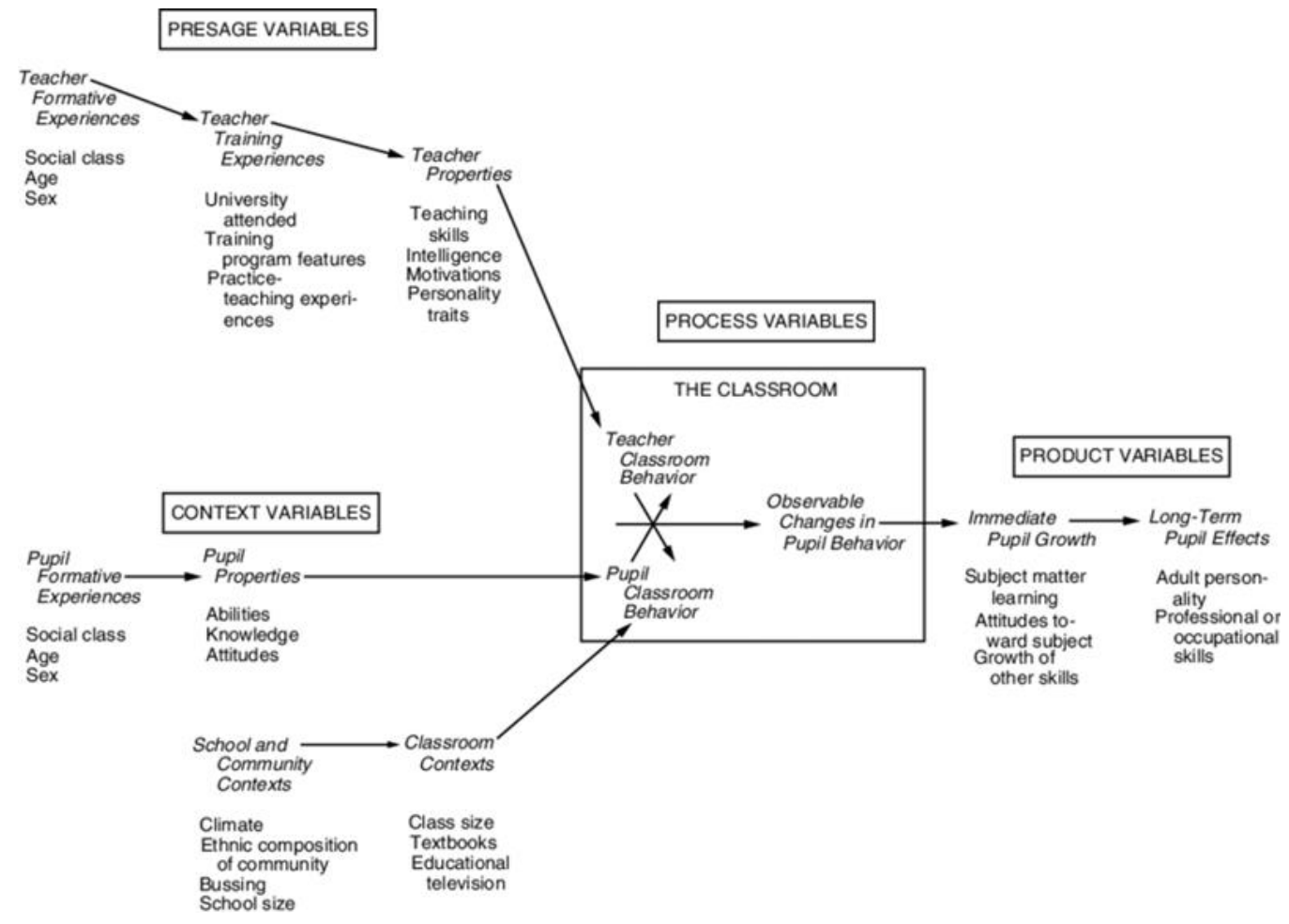

Figure 2. Teaching and Learning Variables Model by Dunkin and Biddle

The classroom interaction model analyses four main categories of variables: presage, context, process and product. First of all, presage variable is the characteristics which teachers as individuals or as a group bring their own formative experiences, training, and personal qualities. Secondly, the context variable consists of the certain properties that belong to students, school, and environment. Specifically, as this second variable deals with students' properties such as attitudes, Adversity Quotient is definitely stated its position in this conception. Moreover, these notions of AQ: students' resilience, tenacity, perseverance, engagement, optimism, and willingness to learn indisputably contributed the process of learning and teaching stated in the third variable. In this stage, teachers' and students' behaviour are interrelated and resulted in the observable changes in pupil behaviour. Lastly, the product variable refers to the outcome of the teaching-learning process as the manifestation of growth in subject-matter learning. Within long term effect, students are expected to master professional or occupational skills based on specified discipline.

In English Language Teaching context, the mastery of subject-matter learning as the branch of product variable can be examined through how proficient individual using the language for certain use. Related to the academic realm, there are numerous international standardized tests that can be used to test individual's English proficiency. (Brown, 2006) provides several example of English proficiency tests for assessing the English proficiency such as TOEFL, TOEIC, IELTS, BULLATS, and MELLABS. Thus, those international standardized tests complete the theorem of product variable in ELT as they offers set of commonly agreed standards in defining English proficiency. 
Based on the observation done by the researcher, second semester students of English Language Teaching Department in State Islamic University Sunan Ampel Surabaya are facing some obstacles that may reduce their learning performance. One of the difficulties is that they need to adapt to a new learning environment which is totally different from senior high school atmosphere. In their previous study, they used to learn any materials prepared by the teacher. In contrast, they are required to be independent learner that utilizes multiple learning sources. Whereas, the new experience came to unable students to do their best performance for their academic achievement.

To sum up, according to the detailed description of Dunkin and Biddle's model previously and comprehensively described, Adversity Quotient undoubtedly plays potential role to the success of teaching-learning process in the classroom. The realm of AQ turns challenges and obstacles to be opportunity. Henceforth, the researcher would like to analyse how the freshmen students deal with their problems as well as overcome them. Thus, this study attempts to investigate the influence of Adversity Quotient toward the success of English learning. Specifically, this research aims at examining the potentials of CORE as the dimension of AQ as well as the predictors of English proficiency among EFL students.

This study aimed to address the following research questions: (1) which dimension of adversity quotient contribute the most on students' English proficiency?, (2) what is the percentage of quitter, camper, and climber group in the second semester students of English Language Teaching Department in UINSA?, and (3) how high do quitter, camper, and climber students achieve in their English proficiency?.

\section{METHOD}

This study applied quantitative approach using multiple regression for data analysis. The setting was at English Language Teaching Department, Faculty of Tarbiyah and Teacher Training, State Islamic University of Sunan Ampel Surabaya. The university was located in Ahmad Yani Street, Number 117, district of Wonocolo, Surabaya, Indonesia 620237. The subject of this research was the second semester students in English Language Teaching Department in Faculty of Tarbiyah and Teacher Training, UIN Sunan Ampel Surabaya. The population is 77 students, consisting 51 female and 16 male.

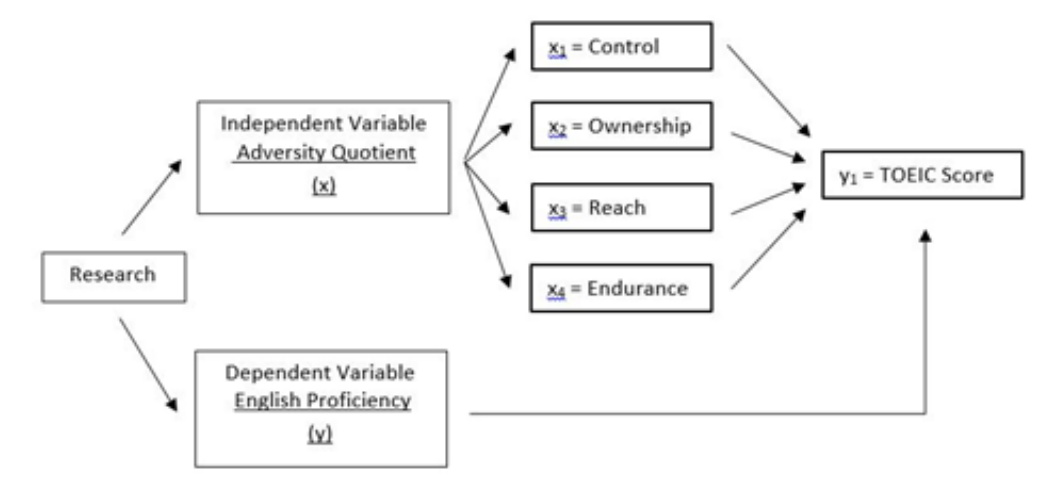

Figure 3. Variables of the Research

The Adversity Quotient acted as independent variable in this research, while the dependent variable was English proficiency. The first variable, Adversity Quotient, had 4 dimensions; Control, Ownership, Reach, and Endurance. AQ score ranged from 0-200, divided the division level into climber, camper, and quitter. Related to the independent variable, English proficiency was indicated by TOEIC score.

There were two instruments used in this research. The first was Adversity Response Profile (ARP). ARP was the only official assessment tool designed to measure an individual's style of responding to adverse situations (Stoltz, 1997). ARP had been tested across respondents from 51 countries and had demonstrated strong universality. The ARP was obtained from emailing Global Resilience Institute (GRI) as the official and licensed Adversity Quotient institution. The reliability of ARP was claimed to be highly reliable and consistent based on a study conducted by an independent psychometrician at Educational Testing Service. The ARP and its four CORE dimension had an overall reliability of .91. Nonetheless, this claim by ARP development team on the official website at www.peaklearning.com needed to be clarified. The researcher conducted a reliability test using Cronbach's Alpha to the 20 items provided in the ARP. Related to the application of ARP itself, the researcher did not change neither the construct nor the content, just conformed the language. Therefore, the researcher consulted the language use and conformity to a professional lecturer that had expertise on linguistics. The advices and recommendation from the expert was necessarily needed to enhance the quality of Adversity Response Profile within the context of this research. 
The second instrument were TOEIC score. It represented students' English proficiency. Conversely, as afore mentioned in the limitation of the study, the English proficiency being tested by TOEIC was only listening and reading. Educational Testing Service (ETS), the organization managing the TOEIC, offered a conversion from TOEIC scores to the levels of the Common European Framework of Reference for Languages (CEFR).

Table 3. Conversion of TOEIC Score to CEFR

\begin{tabular}{ll}
\hline TOEIC Score & \multicolumn{1}{c}{ CEFR } \\
\hline $945-990$ & C1: Advanced \\
\hline $620-940$ & B2: Upper Intermediate \\
\hline $390-615$ & B1: Intermediate \\
\hline $230-385$ & A2: Lower Intermediate \\
\hline $10-225$ & A1: Beginner \\
\hline
\end{tabular}

There are two independent scores for listening and reading on a scale from 5 to 495 points. The two score were added up to a scale from 10 to 990 . Moreover, CEFR offered some levels in equation to TOEIC score. Afterwards, the students' TOEIC score and AQ score were analysed through bivariate multiple regression.

In order to compute the multiple regression analysis, the researcher had to follow good regression linear model and meet the requirement of Classical Assumption. It comprised of three different tests that need to be surpassed. The first test was Multicollinearity to find the correlation among the independent variable. Variation Inflaction Factor (VIF) was used in SPSS during the statistical computation. The second test was Heteroscedaticity. It purposed to analyze inequality variance from obe observation to another observation. Heteroscedaticity test was done by formulating Glejser equations in SPSS. The last test was Normality. It determined the normal distribution data in a model of regression. Kolmogorov-Smirnov test in SPSS was utilized in order to find the distribution.

Hence, the .Classic Assumption Tests were done, the analysis continued to simultaneous and partial regression. Simultaneous regression was purposed to find the contribution of independent variables (Control, Ownership, Reach, Endurance) to dependent variable (TOEIC score) simultaneously. In contrast, partial regression test addressed to find each influence of independent variables as predictors to dependent variable.

\section{FINDING}

\section{Adversity Quotient Score}

The adversity quotient score was obtained through the only official questionnaire namely Adversity Response Profile. In order to get the approval for the AQ instrument, the researcher e-mailed Global Resilience Institute through PEAK Learning, Inc. The Global Resilience Institute offered several requirements before allowing the researcher to use the ARP. The agreement was signed on March 26th, 2019.

The adversity quotient score was obtained through the only official questionnaire namely Adversity Response Profile. In order to get the approval for the AQ instrument, the researcher e-mailed Global Resilience Institute through PEAK Learning, Inc. The Global Resilience Institute offered several requirements before allowing the researcher to use the ARP. The agreement was signed on March 26th, 2019.

Afterwards, the researcher distributed the Adversity Response Profile in order to obtain the students' AQ score. The questionnaire dissemination was one week, started from April 1st, 2019 to April 5th, 2019. Along with the permission from the Head of English Language Teaching Department, the researcher distributed the ARP to Spoken English Class A1, B1, and C1 in order to gain access to the whole second semester students.

There were 8 students who were absent on that day and one student did not cooperate by giving a fake identity. Although this student was identifiable, the researcher decided to take her out. The reason was that fake identity may disrupt the result of the regression between predictors variable to students' English proficiency indicated by TOEIC score. In short, there were nine students who did not fill the Adversity Response Profile. This is the description of adversity quotient score. 


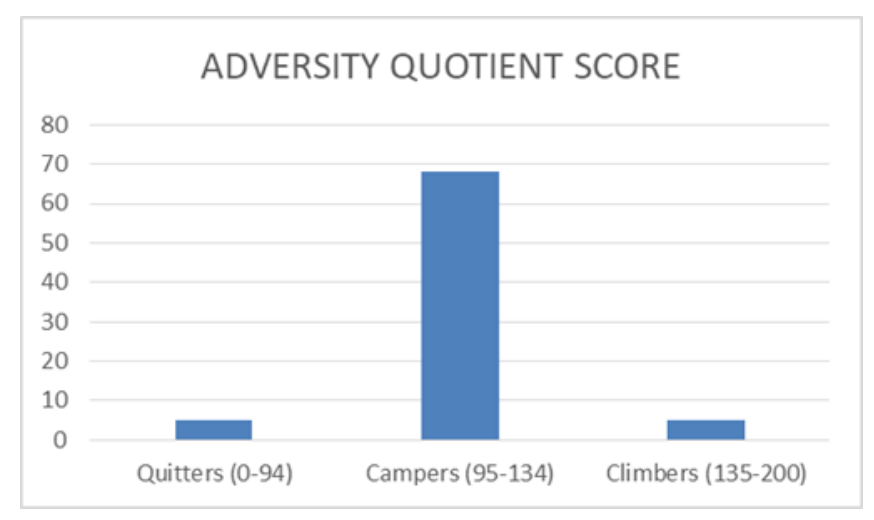

Figure 4. Adversity Quotient Score of Second Semester Students

Figure 4 was quite revealing. It informed the distribution students to three adversity quotient levels: quitters, campers, and climbers. There were five students grouped as quitters (6.4\%), 67 students as campers (87.2\%), and five students as climbers (6.4\%). As previously requested, this data was reported to English Language Teaching Department in UINSA for further internal handling by the institution.

\section{TOEIC Score}

Based on the official name list from English Language Teaching Department, there are 87 students registered in semester II. However, only 80 students had taken TOEIC test at the end of the semester I. There were three students were absent during the test. This was the description of the second semester students' English proficiency benchmarked by Language Development Center TOEIC Equivalent.

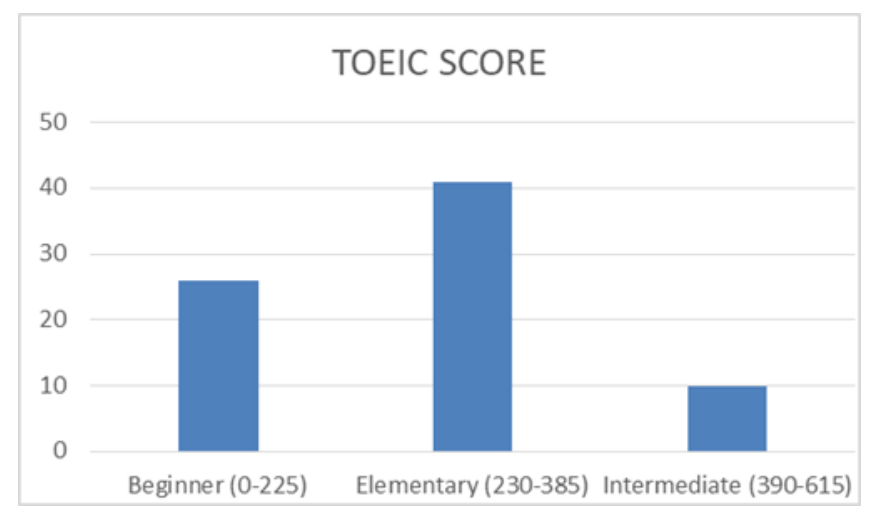

Figure 5. TOEIC Score of Second Semester Students

Figure 5 informed several interpretation level to the TOEIC score. There were 26 students included as beginners ( 0 230). In this level, they are considered to have very limited proficiency. Beginner students were expected to understand days of the week, months of the year, simple social questions, memo, and very basic conversation.

The upper level of beginner was called lower intermediate (230-385). There were 41 students in this group. They had adequate limitation to use their listening and reading skills. Lower intermediate students were able to understand slow talk, deliberate discussion, broadcasted announcement, short discussion, product information, and casual conversation.

The next level was intermediate (390-615). There were 10 students assembled in this group. Test takers were considered to have mediocre English proficiency. Intermediate students were able to understand English newspaper, popular novel, entertainment-related information, meeting demonstration, radio headlines, and workplace discussion. 


\section{Empirical Validity Test}

Empirical validity was a statistical evidence determined by using the Pearson correlation coefficient. The Pearson formula was used as a tool for fulfilling the satisfactory of statistical assumption. The significance level for education research was agreed as $(\alpha)=5 \%$ with degree of freedom $76(\mathrm{df}=\mathrm{n}-2)$. Based on the formulation, rtable was obtained as 0.222 . The item was valid if $r>$ rtable. In contrast, the item was denied if $r<$ rtable. Table 4 informed that the 20 items represent the four dimension of adversity quotient namely CORE (Control, Ownership, Reach, and Endurance). All items were considered valid as each $r>$ rtable. Therefore, item elimination was not merely necessary.

\section{Internal Consistency Reliability Test}

Internal consistency reliability was the most important coefficient for estimating consistency of items. The tool for this analysis was Cronbach's Alpha. The scores of AQ were correlated with among themselves. From the table 5, the reliability of Adversity Response Profile was obtained as .739. To sum up, the items used as the questionnaire have passed both internal consistency reliability and concurrent validity test.

Table 4. Validity Test

\begin{tabular}{ccccc}
\hline Dimension & Items & $\mathbf{r}$ & rtable. & Statement \\
\hline \multirow{5}{*}{ Control } & 1 & .254 & .222 & Valid \\
& 7 & .383 & .222 & Valid \\
& 13 & .223 & .222 & Valid \\
& 15 & .366 & .222 & Valid \\
& 17 & .365 & .222 & Valid \\
\hline \multirow{5}{*}{ Ownership } & 2 & .242 & .222 & Valid \\
& 6 & .467 & .222 & Valid \\
& 11 & .242 & .222 & Valid \\
& 16 & .425 & .222 & Valid \\
Reach & 18 & .384 & .222 & Valid \\
\hline & 3 & .269 & .222 & Valid \\
& 5 & .653 & .222 & Valid \\
& 9 & .657 & .222 & Valid \\
Endurance & 12 & .378 & .222 & Valid \\
& 20 & .405 & .222 & Valid \\
\hline & 4 & .660 & .222 & Valid \\
& 10 & .253 & .222 & Valid \\
& 14 & .411 & .222 & Valid \\
& 19 & .463 & .222 & Valid \\
\hline
\end{tabular}

Table 5. Reliability Test

\begin{tabular}{cc}
\hline Cronbach's Alpha & N of Items \\
\hline .739 & 20 \\
\hline
\end{tabular}

Multicollinearity Test

Multicollinearity test (table 6) was conducted in order to analyze the correlation between independent variables in one regression model. Multicollinearity problem appeared if there was strong correlation manifested by the value of Variance Inflation Factor (VIF) < 10 and tolerance $>.10$. The multicollinearity test (table 6) showed the VIF value of 4 independent variables. Specifically, the VIF of Control (1.527), Ownership (1.429), Reach (1.107), and Endurance (1.112) are >10. Thus, it could be concluded that multicollinearity problem was not found. The data surpassed the multicollinearity test and continued to the next basic assumption. 
Table 6. Multicollinearity Test

\begin{tabular}{|c|c|c|c|c|c|c|c|c|}
\hline & \multirow[t]{2}{*}{ Model } & \multicolumn{2}{|c|}{ Unstandardized Coefficients } & \multirow{2}{*}{$\begin{array}{c}\text { Standardized Coefficients } \\
\text { Beta }\end{array}$} & \multirow[t]{2}{*}{$\mathbf{t}$} & \multirow[t]{2}{*}{ Sig. } & \multicolumn{2}{|c|}{ Collinearity Statistics } \\
\hline & & B & Std. Error & & & & Tolerance & VIF \\
\hline \multirow[t]{5}{*}{1} & (Constant) & 224.334 & 76.366 & & 2.938 & .004 & & \\
\hline & Control & 1.035 & 3.322 & .041 & .312 & .756 & .655 & 1.527 \\
\hline & Ownership & 9.238 & 3.164 & .375 & 2.919 & .005 & .700 & 1.429 \\
\hline & Reach & .067 & 3.203 & .002 & .021 & .983 & .903 & 1.107 \\
\hline & Endurance & .072 & 2.172 & .004 & .033 & .974 & .899 & 1.112 \\
\hline
\end{tabular}

\section{Heteroscedaticity Test}

Normality test was used to determine the normality of the error term and variable, both independent and dependent variables. A decent regression model should follow the normal distribution of data or close to normal. Thus, Kolmogorov-Smirnov test in SPSS was utilized in order to find the distribution (table 7). Kolmogorov-Smirnov test was done with the value of unstandardized residual. The result showed that asymptotic significance is $.998>.005$. This means that the regression model fulfill the normal data distribution.

Table 7. Heteroscedaticity Test

\begin{tabular}{ccc}
\hline & & Unstandardized Residual \\
\hline $\mathbf{1}$ & & $\mathbf{7 7}$ \\
\hline Normal Parameters $^{\mathrm{a}}$ & Mean & .0000000 \\
& Std. Deviation & 73.04386774 \\
\hline Most Extreme Differences & Absolute & .045 \\
& Positive & .044 \\
& Negative & -.045 \\
\hline Kolmogorov-Smirnov Z & .396 \\
Asymp. Sig. (2-tailed) & .998 \\
\hline
\end{tabular}

\section{Coefficient Determination}

Coefficient determination (R2) was a measurement that assessed the ability of a model to predict or explain an outcome on linear regression setting. In short, it was the value of how dependent variable (TOEIC Score) were influenced by independent variables (Control, Ownership, Reach, and Endurance).

Table 8. Coefficient Determination

\begin{tabular}{ccccc}
\hline Model & R & R Square & Adjusted R Square & Std. Error of the Estimate \\
\hline 1 & $.399^{\mathrm{a}}$ & .159 & .113 & 74.987 \\
\hline
\end{tabular}

The coefficient determination (R2) was obtained as 0.159 . This meant that $15.9 \%$ of TOEIC score was explained by Control, Ownership, Reach, and Endurance. In addition, the formulation above also generated coefficient of non-determination as $83.1 \%$. It was the amount of unexplained variance between two variables. The function of coefficient non-determination was as the numerator of the standard error formula that was beyond the analysis of this research.

\section{Simultaneous Regression}

Simultaneous regression test was conducted in order to find the contribution of independent variables (Control, Ownership, Reach, Endurance) to dependent variable (TOEIC score) simultaneously. There were some procedures that needed to be followed, described as below:

A. Hypothesis of Simultaneous Regression

Ho : There is no influence between Control, Ownership, Reach, and Endurance on English proficiency simultaneously. $\mathrm{Ha}$ : There is influence between Control, Ownership, Reach, and Endurance on English proficiency simultaneously.

B. Determination of Significance Level

The level of significance was $5 \%$, followed by $95 \%$ level of confidence.

C. Simultaneous Regression Test

This as the result of simultaneous regression test based on SPSS. 
Table 9. Simultaneous Regression

\begin{tabular}{llccccc}
\hline & Model & Sum of Squares & df & Mean Square & F & Sig. \\
\hline 1 & Regression & 77565.533 & 4 & 19391.383 & 3.44 & $.000^{\text {a }}$ \\
& Residual & 410483.338 & 73 & 5623.059 & & \\
& Total & 488048.872 & 77 & & & \\
\hline
\end{tabular}

According to table 9, F was obtained as 3.44. Ho was rejected and Ha was accepted if F > Ftable. The Ftable for degree of freedom (df) $5 \%$ significance level, 77 number of participant $(\mathrm{N})$, and 4 predictors (k) was 2.33. In short, Ho was rejected and Ha was accepted because $3.44(\mathrm{~F})>2.33$ (F table). Based on the explanation aforementioned, it could be concluded that there was significant influence between Control, Ownership, Reach, and Endurance simultaneously on English proficiency, indicated by TOEIC score.

\section{Partial Regression}

Partial regression test was done in order to find each influence of independent variables as predictors to dependent variable. This table below represented the result of statistical data in SPSS. Similar with simultaneous regression, there were some steps to be followed described as below.

A. Hypothesis of Partial Regression

Ho : There is no influence between Control, Ownership, Reach, and Endurance on English proficiency partially.

$\mathrm{Ha}$ : There is influence between Control, Ownership, Reach, and Endurance on English proficiency partially.

B. Determination of Significance Level

The level of significance was $5 \%$, followed by $95 \%$ level of confidence.

C. Partial Regression Test

This was the result of partial regression test based on SPSS.

Table 10. Partial Regression

\begin{tabular}{llccccc}
\hline \multirow{2}{*}{ Model } & \multicolumn{2}{c}{ Unstandardized Coefficients } & Standardized Coefficients & \multirow{2}{*}{ t } & \multirow{2}{*}{ Sig. } \\
\cline { 2 - 5 } & (Constant) & 238.426 & Std. Error & Beta & & \\
\hline \multirow{2}{*}{1} & 9.445 & 62.248 & & & .830 & .000 \\
& Control & 3.260 & .383 & 2.897 & .005 \\
& Ownership & .042 & 3.153 & .002 & .013 & .989 \\
& Reach & .812 & 3.364 & .035 & .241 & .810 \\
& Endurance & -.880 & 2.402 & -.053 & -.367 & .715 \\
\hline
\end{tabular}

Table 10 was quite revealing in several ways. There were four predictors being analyzed: Control (2.897), Ownership (.13), Reach (.241), and Endurance (-.367). Ho was rejected and Ha was accepted if $\mathrm{t}>\mathrm{t}$ table. The ttable for the degree of freedom (df) with $5 \%$ significance level and 77 number of participant $(\mathrm{N})$ ws obtained 1.66. Based on the result above, only predictor Cont rol had significantly influenced to TOEIC score $(2.89>1.66)$. Further analysis showed that the other predictors such as Ownership, Reach, and Endurance had also not significantly influenced the TOEIC score (>.166).

\section{DISCUSSION}

Interestingly, the dissemination of Adversity Response Profile to the 77 subjects of the research resulted on predictive percentage. There were five students grouped as quitters $(6.4 \%), 67$ students as campers $(87.2 \%)$, and five students as climbers (6.4\%). On the other hand, the proportion of students to the levels of AQ in this research supported the statement of (Stoltz, 1997), the campers always have the tendency to outnumber quitters and climbers.

The result of TOEIC test of second semester students was also predictable: almost similar with bell-curved shape. There were 26 students $(33.76 \%)$ in beginner level $(0-230), 42$ students $(62.68 \%)$ in lower intermediate level (230-385), and 11 (16.41) students in intermediate level (390-615). In specific, each levels of AQ had unique distribution of the result of TOEIC test. Firstly, five Quitters were comprised of four beginners (80\%) and one lower intermediate (20\%). Secondly, 67 Campers consisted of 36 lower intermediates (53.73\%), 22 beginners (32.83\%), and nine intermediates (13.44\%). Lastly, five Climbers were made up of four lower intermediates $(80 \%)$, and one intermediate $(20 \%)$. 
The distribution of the result of TOEIC test in conformity with the levels of AQ had been previously expected by the researcher. The Quitters, as the lowest level of AQ, was mostly comprised of beginners (80\%) as the lowest grade of TOEIC. The Campers, as the mediocre level, seemed to have more flexibility by comprising beginner, lower intermediate, and intermediate score concurrently. Yet, as predicted, the majority of the Campers was still composed by average score (lower intermediate $53.73 \%$ ). The exceptional result was the composition of Climbers. The highest AQ level supposedly consisted of intermediate score as the highest level of TOEIC test obtained by the students. Surprisingly, the Climbers, was minored by only one student who obtained intermediate score $(20 \%)$, followed by lower intermediate $(80 \%)$ as the medium score. In order to investigate the oddness, the relationship between Adversity Quotient and TOIEC score should be prudently analyzed. The analysis between the two variables was statistically assessed through the coefficient determination, partial regression, and simultaneous regression.

Based on the coefficient determination output data result, the R2 was obtained as .159. It meant that the CORE of Adversity Quotient contributed $15.9 \%$ to the students' English proficiency as indicated by their TOEIC score. The result did resonance with a number of research of AQ in the realm of multidisciplinary science education. The research conducted by (Matore et al., 2015) explained that AQ was obviously associated with academic achievement of polytechnic students but not greatly influence the dependent variable as it only contributed 0.9\%. Another research by (City, 2009) recorded only 7.18\% change in the respondents' Grade Point Average (GPA) influenced by AQ. In the mathematic studies, (Amparo, 2015) also shared the common outcome that AQ contributed 8.18\% to mathematical achievement. On the other hand, contrary to expectations, these findings were theoretically very opposite to the AQ concept which serve it as a global success predictor as previously stated by (Stoltz, 1997; Tripathi, 2011)

In correspondence with the minor contribution of Adversity Quotient to academic achievement, specifically in English proficiency, the result of simultaneous and partial regression added some obvious proofs. Even though there was simultaneous influence of Core, Ownership, Reach, and Endurance to the TOEIC score, the F value (3.44) was just slightly above Ftable (2.33). Furthermore, based on the result of the partial regression analysis, only one predictor (Control), out of 3 (Ownership, Reach, and Endurance), had influenced significantly to the dependent variable (TOEIC score). The result of the partial regression to some extent weakened the statement of AQ as a factor influencing students' academic achievement.

Nevertheless, as shown in the result of partial regression, the contribution of control that dominated the other three predicting variables should not be left unnoticed. This result confirmed a resonance with numerous research on related to the contribution of AQ to multidisciplinary studies. (Utami \& Hawadi, 2009) found that the Control variable of AQ contributed significantly to students' achievement in mathematics and natural sciences. Another research by (Mwivanda \& Kingi, 2019) stated that AQ dimension of control influenced students' academic performance. A rational explanation for those results were described (Stoltz, 1997). He stated that control, as a dimension of Adversity Quotient, consisted of two tendencies that scientifically contributed to the success of academic achievement. They are resilience and tenacity.

The first tendency, resilience, was also an interesting area of research that had important implications for the educational improvement of English Language Learners (ELLs). (Luthar, Lyman, \& Crossman, 2014), to some extent, placed and described the position of resilience precisely in this research. He stated that resilience is that of individual competence and success despite severe and prolonged adversity. In addition, there were numerous research that supported the contribution of resilience to students' achievement. A study conducted by (Eller, 2012) resulted that there was significant difference between resilient and non-resilient students on their English achievement. Another research conducted by Padrón, Waxman, Brown, \& Powers (2000) also showed that students with high resilience had tendency to obtain higher standardized achievement test, daily school assignments, and had excellent attendance. In short, resilience was both theoretical and empirical framework that concerned on indicators or behaviours that promote students' success.

The second tendency was tenacity. As a non-cognitive factor, it promoted long-term learning and achievement in academic process (Dweck, Walton, \& Cohen, 2014). In addition, (City, 2009) also added that tenacity required self-discipline and self-control. He suggested that tenacity was a manifestation of mental toughness as a requirement for students to be successful in their academic disciplines. Similar with resilience, there were abundant research that examined the role of tenacity with the academic success. A study by (Arslan, Akin, \& Çitemel, 2013) found a useful relationship between tenacity aspects and students' metacognitive awareness.

To conclude, this research had statistically proven that Adversity Quotient provided minor contribution to students' English proficiency indicated by their TOIEC score. The result was drawn from the outcome of multiple regression analysis that demonstrated only one predictor (control) was significant to the dependent variable (TOEIC score), out of other three (Ownership, Reach, and Endurance). Nevertheless, the contribution of Control as the only significant predictor to English proficiency should not be effortlessly underrated. Yet, it comprised of resilience and tenacity that had academically proved by abundant research to bring prodigious contribution to the success of academic achievement. 


\section{CONCLUSION}

This research had statistically proven that Adversity Quotient provided minor contribution to students' English profifiency indicatedby their TOEIC score. The result was drawn from the outcome of multiple regression analysis that demonstrated only one predictor (control) was significant to the dependent variable (TOEIC score). Nevertheless, the contribution of control as the only significant predictor to English proficiency should not be effortlessly underrated. Yet, it comprised of resilience and teanacity that had academically proved by abundant research to bring prodigious contribution to the success of academic achievement. This research had proven statistically that tenacity and resilience positively associated to English proficiency.

This result was also supported by numerous research that showed tenacity and resilience theoretically contributed to academic achievement. Thus, the researcher recommended English Language Teaching Department to encourage students' tenacity and resilience during the process of language teaching and learning in the classroom.

The researcher of the present study expects other studies to be conducted on investigating two aspects that could not be covered in this research. The first aspect is the contribution of AQ and its dimensions to English productive skill such as speaking and writing. The second aspect is the coefficient non-determination $83.1 \%$ founded in this research. This is a potential research gap for other researchers to be studied using standard error of estimation formula.

\section{REFERENCES}

Ader, R. (2000). On the Development of Psychoneuroimmunology. European Journal of Pharmacology, 405(1-3), 167-176.

Amparo, M. M. (2015). The Level of Adversity Quotient and Social Skills of Student Leaders at De La Salle Lipa.

Arslan, S., Akin, A., \& Çitemel, N. (2013). The Predictive Role of Grit on Metacognition in Turkish University Students. Studia Psychologica, 55(4), 311. https://doi.org/https://doi.org/10.21909/sp.2013.04.645

Bakare, B. M. (2015). Students' Adversity Quotient ${ }^{\circledR}$ and Related Factors as Predictors of Academic Performance in the West African Senior School Certificate Examination in Southwestern Nigeria. University of Ibadan.

Carroll, J. (1999). Wilson's Consilience and Literary Study. Philosophy and Literature, 23(2), 393-413.

Dweck, C. S., Walton, G. M., \& Cohen, G. L. (2014). Academic Tenacity: Mindsets and Skills that Promote Long-Term Learning. Bill \& Melinda Gates Foundation.

Luthar, S. S., Lyman, E. L., \& Crossman, E. J. (2014). Resilience and Positive Psychology. In Handbook of Developmental Psychopathology (pp. 125-140). https://doi.org/https://doi.org/10.1007/978-1-4614-9608-3_7

Marashi, H., \& Fotoohi, M. (2017). The Relationship Between Extrovert and Introvert EFL Teachers' Adversity Quotient and Professional Development. Journal of Applied Linguistics and Language Research, 4(3), 156-170.

Matore, M. E. E. M., Khairani, A. Z., \& Razak, N. A. (2015). The Influence of AQ on the Academic Achievement among Malaysian Polytechnic Students. International Education Studies, 8(6), 69-74.

Mohzan, M. A. M., Hassan, N., \& Halil, N. A. (2013). The Influence of Emotional Intelligence on Academic Achievement. Procedia-Social and Behavioral Sciences, 90, 303-312. https://doi.org/https://doi.org/10.1016/j.sbspro.2013.07.095

Mwivanda, M., \& Kingi, P. M. (2019). Teachers' Adversity Quotient Dimension of Control and Students Academic Performance in Secondary Schools in Kenya. Journal of Education and Training, 6(1), 83. https://doi.org/https://doi.org/10.5296/jet.v6i1.14373

Praditsang, M., Hanafi, Z., \& Walters, T. (2015). The Relationship among Emotional Intelligence, Social Intelligence and Learning Behaviour. Asian Social Science.

Rahmayani, A. (2013). Hubungan Antara Kecerdasan Intelektual dengan Adversity Quotient pada Peserta Didik MTs Darul Karomah. Tesis tidak diterbitkan. Universitas Islam Negeri Maulana Malik Ibrahim, Malang.

Rogawski, M. A. (2017). Current Protocols in Neuroscience. Neurophysiology, 6, 1-17. https://doi.org/https://doi.org/10.1002/0471142301.ns0600s38

Sihaloho, R. R., \& Sahyar, E. M. G. (2017). The Effect of Problem Based Learning (PBL) Model toward Student's Creative Thinking and Problem Solving Ability in Senior High School. Journal of Research \& Method in Education State University of Medan, 7(4), 11-18. https://doi.org/https://doi.org/10.9790/7388-0704011118

Stenberg, R., \& Stenberg, K. (2012). Cognitive Psychology (Sixth Edit). Wadsworth: Cengage Learning.

Suryadi, B., \& Santoso, T. I. (2017). Self-Efficacy, Adversity Quotient, and Students' Achievement in Mathematics. International Education Studies, 10(10), 12-19.

Tripathi, S. (2011). Use of Adversity Quotient (AQ) in Creating Strong Busine ss Leaders of Tomorrow. Doctoral thesis.

Utami, A. B., \& Hawadi, L. F. (2009). The Contribution of Adversity Quotient on High School Acceleration Learning Student at Jakarta. Jurnal Ilmiah Psikologi, 11(2).

Venkatesh, J., \& Shivaranjani, G. (2016). Adversity Quotient Profile: A Robust Assessment Tool to Measure Human Resilience. Asian Journal of Research in Social Sciences and Humanities, 6(6), 412-426. https://doi.org/https://doi.org/10.5958/2249-7315.2016.00219.7 